\title{
Suberoyl bis-hydroxamic acid activates Notch1 signaling and induces apoptosis in anaplastic thyroid carcinoma through p53
}

\author{
JIANSEN LI ${ }^{1}$, XIANGQIAN ZHENG ${ }^{2}$, MING GAO ${ }^{2}$, JINGZHU ZHAO ${ }^{2}$, \\ YIGONG LI $^{2}$, XIANGRUI MENG ${ }^{3}$, BIYUN QIAN ${ }^{4}$ and JIAFENG LI ${ }^{1}$ \\ Departments of ${ }^{1}$ Anesthesiology, ${ }^{2}$ Thyroid and Neck Tumor, and ${ }^{3}$ Lymphoma, \\ Tianjin Medical University Cancer Institute and Hospital, Key Laboratory of Cancer Prevention and Therapy, \\ Tianjin National Clinical Research Center for Cancer, Tianjin 300060; ${ }^{4}$ Department of Epidemiology, \\ School of Public Health, Shanghai Jiao Tong University, Shanghai 200030, P.R. China
}

Received June 2, 2016; Accepted October 31, 2016

DOI: 10.3892/or.2016.5281

\begin{abstract}
Anaplastic thyroid cancer (ATC), usually derived from well-differentiated thyroid cancers is one of the most lethal human endocrine malignancies. In the present study, we report that in human ATC tumor tissue samples exist undetectable Notch1 and the active Notch1 intracellular domain could not be detected in ATC-CAL-62 cells. Interesting, suberoyl bis-hydroxamic acid (SBHA) administration could induce Notch1 intracellular domain levels in a dose-dependent manner, coupled with the increase of p53 and p21. Furthermore, ectopic expression of Notch1 or deletion of p53 with smallinterfering RNA was able to abolish the effects of SBHA to elevation of Notch1 and p53 in ATC cells. As a result, SBHA treatment efficiently induced ATC cell apoptosis. These results indicate that SBHA may play antitumor functions via regulating Notch1/p53 signals, and highlight that SBHA could have clinical potential to benefit the therapy of ATC patients.
\end{abstract}

\section{Introduction}

Thyroid cancer is the most prevalent endocrine malignancy accounting for $1 \%$ of cancers worldwide. Follicular thyroid cancer (FTC) and papillary thyroid cancer (PTC) are differentiated tumors that respond to surgery followed by radioactive iodine (RAI) therapy and thyroid hormone suppression. On the other hand, anaplastic thyroid cancer (ATC) is an undifferentiated thyroid cancer, and one of the most deadly solid human malignancies. ATC ranges from 1.3 to $9.8 \%$ of all thyroid cancers globally, but accounts for nearly

Correspondence to: Dr Ming Gao, Department of Thyroid and Neck Tumor, Tianjin Medical University Cancer Institute and Hospital, Key Laboratory of Cancer Prevention and Therapy, Tianjin National Clinical Research Center for Cancer, Huanhuxi Road, Ti-Yuan-Bei, Hexi, Tianjin 300060, P.R. China

E-mail: headandneck15@aliyun.com

Key words: anaplastic thyroid cancer, suberoyl bis-hydroxamic acid, Notch1, p53, p21, apoptosis one-third of thyroid cancer deaths (1-3). The median survival of patients with ATC is less than 6 month, and $90 \%$ of patients with ATC present with unresectable locally advanced or distant metastatic disease at time of diagnosis (3-6). Clinical presentation is frequently characterized by a rapidly growing neck mass with associated compressive symptoms (7). ATC also displays highly invasive behavior, with extrathyroid extension and lymph node metastasis affecting $40 \%$ of ATC patients, whereas the remaining $60 \%$ of patients have distant metastases (8). The aggressive phenotype and poor prognosis associated with ATC form the basis for its automatic classification as TNM stage IV regardless of tumor burden (9). ATC is a disease with low survival rate due to uncontrolled systemic metastasis and with less effective treatment options. It is resistant to standard chemotherapy, external beam radiation, and radioiodine treatment, thus, new treatments are urgently desired.

The Notch pathway is a highly evolutionally conserved molecular pathway that plays an important role for cell fate determination, proliferation, differentiation and survival in development, neurogenesis and homeostasis $(10,11)$. There are four Notch proteins (NOTCH1-4) that function as receptors for five Notch ligands [Delta-like (DIl) 1, -3, -4 and JAG1 and -2] in mammalians. The interactions between Notch receptor and ligand result in proteolytic cleavages finally leading to the release of the Notch intracellular domain (NICD) that translocates to the nucleus and associates with DNA-binding proteins to assemble a transcriptional complex to activate downstream target genes (12). Recent years have seen major advances in the understanding of the dual function of Notch1 signaling as both an oncogene and a tumor suppressor $(13,14)$. Aberrant Notch signaling has been associated with various cancers, including thyroid cancers (15). For epithelial thyroid cancers, it has been found that the expression level of activated Notch1 (NICD) is much lower in human thyroid cancer tissue compared with normal thyroid tissue, which has abundant NICD (15). Similar findings have been reported in another study, which shows that the downregulation of Notch1 signaling in thyroid tumors is associated with the dedifferentiated phenotype of ATC. Furthermore, overexpression of Notch1 restores the differentiated phenotype of thyroid cancer cells (16). Based on these 
findings, Notch1 pathway activating compounds could be employed as a potential therapeutic strategy for ATC.

Recent research has also shown that the Notch signaling pathway is regulated by a histone deacetylase (HDAC) co-repressor complex that is sensitive to HDAC inhibitors (17). As histone deacetylase (HDAC) inhibitors have the ability to block the activities of HDACs to subsequently emerge as effective anticancer agents $(18,19)$. Suberoyl bishydroxamic acid (SBHA) has a similar structure to HDAC inhibitors, such as suberoylanilide hydroxamic acid (SAHA) and trichostatin A (TSA), two of the mostly studied HDAC inhibitors. Thus, we hypothesized that SBHA may be able to affect the Notch1 signaling cascade by manipulating HDACs.

\section{Materials and methods}

Cell culture and reagents. Human ATC cells (CAL-62) were obtained from Shanghai Institute of Biochemistry and Cell Biology (SIBCB), Shanghai Institutes for Biological Sciences (SIBS) and Chinese Academy of Sciences (CAS) and maintained in Dulbecco's modified Eagle's medium (DMEM) supplemented with $10 \%$ fetal bovine serum (FBS), 100 IU/ $\mathrm{ml}$ penicillin and $100 \mu \mathrm{g} / \mathrm{ml}$ streptomycin in a humidified atmosphere of $5 \% \mathrm{CO}_{2}$ in air at $37^{\circ} \mathrm{C}$. SBHA (Beijing Solarbio Science and Technology, Co., Ltd., Beijing, China) was dissolved in dimethyl sulfoxide (DMSO) at a stock concentration $50 \mathrm{mg} / \mathrm{ml}$ and stored at $-20^{\circ} \mathrm{C}$. Fresh dilutions in medium were made for each experiment.

Cell viability assay. Drug sensitivity of ATC cells growing in a monolayer was determined by the methylthiazolyldiphenyltetrazolium bromide (MTT) assay as previously described (20). Briefly, cells were plated at a density of 2,000 cells/well on 96-well plates in quadruplicate and incubated overnight under standard conditions to allow cell attachment. The cells were then treated with SBHA in concentrations of $0-20 \mu \mathrm{M}$ and incubated for up to $48 \mathrm{~h}$. After the treatment medium was removed, $200 \mu \mathrm{l}$ of serum-free medium containing $0.5 \mathrm{mg} / \mathrm{ml}$ MTT was added to each well and incubated for $4 \mathrm{~h}$ at $37^{\circ} \mathrm{C}$. MTT formazan crystals were dissolved by adding $150 \mu \mathrm{l}$ of dimethyl sulphoxide in each well and the absorbance was measured at $570 \mathrm{~nm}$ in a spectrophotometer (DU640; Beckman Coulter, Brea, CA, USA).

Notch1 RNA interference assays. Small-interfering RNA (siRNA) against Notch1 and non-specific siRNA (Shanghai GenePharma, Co., Ltd., Shanghai, China) were transfected into CAL-62 cells according to the manufacturer's instructions. Briefly, CAL-62 cells were plated at a density of 30-60\% confluency in 6-well plates. The next day, transfection with siRNA using Lipofectamine 2000 was carried out, $6 \mathrm{~h}$ later, the medium was changed with complete medium and after $24 \mathrm{~h}$, the cells were treated either with or without SBHA $(15 \mu \mathrm{M} / \mathrm{l})$ for another $48 \mathrm{~h}$. Cell lysates were prepared and western blot analysis was done as described below for Notch1 and other desired proteins.

Western blot analysis. ATC cells were treated with SBHA at various concentrations for $24 \mathrm{~h}$. Then, the cells were washed twice with PBS before the lysis buffer was added. The protein lysates were prepared as previously described (21). Protein concentration was quantified using the BCA protein assay kit (Thermo Fisher Scientific) following the manufacturer's instructions. Cellular extracts $(30 \mu \mathrm{g})$ were denatured by boiling for $5 \mathrm{~min}$ and separated by 8 or $10 \%$ SDS-PAGE. Proteins were transferred onto nitrocellulose membranes (BioRad Laboratories, Hercules, CA, USA), blocked in 5\% non-fat milk solution, and exposed to primary and secondary antibodies as described. The following primary antibody dilutions were used: NICD (1:1,000), p53 (1:1000), p21 (1:1,000), cleaved poly(ADP-ribose) polymerase (PARP; 1:1,000), cleaved caspase-3 (1:1,000), GAPDH (1:1,1000 all from Cell Signaling Technology, Beverly, MA, USA) and $\beta$-actin $(1: 2,000)$. Primary antibody incubations were kept overnight at $4^{\circ} \mathrm{C}$ and then, depending on the antibody, membranes were washed three times $10 \mathrm{~min}$ in wash buffer $(0.1 \%$ Tween-20 in phosphate-buffered saline). Next, the membranes were incubated with a 1:4,000 dilution of horseradish peroxidase-conjugated anti-mouse secondary antibody (for actin) (Cell Signaling Technology) or anti-rabbit secondary antibody (for NICD, cleaved caspase-3, cleaved PARP, p53, p21 and GAPDH). The immunoreactive protein bands were visualized by the detection systems of Immun-Star (Bio-Rad Laboratories), SuperSignal West Pico, or SuperSignal West Femto (Pierce Biotechnology, Rockford, IL, USA). Immunoblot analyses were repeated at least twice and the expression levels of $\beta$-actin or GAPDH were used as the loading control.

Detection of cell apoptosis by flow cytometry. Cell apoptosis was detected by flow cytometric analysis using PE Annexin V apoptosis detection kit I (BD Biosciences, San Diego, CA, USA) according to the manufacturer's instructions. In brief, ATC cell lines were seeded in a 6-well plate and treated with SBHA at different concentrations for 24 or $48 \mathrm{~h}$. Cells were harvested and resuspended in binding buffer $(10 \mathrm{mmol} / \mathrm{l}$ HEPES/NaOH, pH 7.4, $140 \mathrm{mmol} / \mathrm{l} \mathrm{NaCl}$ and $2.5 \mathrm{mmol} / \mathrm{l}$ $\left.\mathrm{CaCl}_{2}\right)$ at a concentration of $1 \times 10^{6}$ cells $/ \mathrm{ml}$. Then PE $(5 \mu \mathrm{l})$ and Annexin V $(5 \mu \mathrm{l})$ were added to $100 \mu \mathrm{l}$ of each sample. Cells were gently mixed and incubated for $15 \mathrm{~min}$ at room temperature in the dark followed by the addition of another $200 \mu \mathrm{l}$ of binding buffer. Stained cells were acquired within $1 \mathrm{~h}$ on FACSCalibur (Becton Dickinson, Franklin Lakes, NJ, USA) and data were analyzed by FlowJo software.

Quantitative real-time PCR. Total RNA was isolated from cultured cells $24 \mathrm{~h}$ after SBHA treatment using silica-gel membrane based spin-column technology (Qiagen). Each RNA sample was examined by electrophoresis on a formaldehyde agarose gel and was quantified by NanoDrop (Thermo Fisher Scientific) to ensure the purity and integrity of RNA. Total RNA $(2 \mu \mathrm{g})$ was reverse transcribed using the iScriptc DNA Synthesis kit (Bio-Rad Laboratories). Sequences for each pair of PCR primers are listed in Table I. The quantitative real-time PCR reactions were conducted on MyiQ Thermal cycler (Bio-Rad Laboratories). Target gene expression was normalized to glyceraldehyde 3-phosphate dehydrogenase (GAPDH) levels in respective samples as an internal standard, and the comparative cycle threshold $(\Delta \mathrm{Ct})$ method was used to calculate relative expression levels of target genes. 
Table I. Sequences for each pair of PCR primers.

Forward primers

Reverse primers

\begin{tabular}{lll}
\hline Notch1 & F: 5'-GTCAACGCCGTAGATGACCT-3' & R: 5'-TTGTTAGCCCCGTTCTTCAG-3' \\
HES1 & F: 5'-TTGGAGGCTTCCAGGTGGTA-3' & R: 5'-GGCCCCGTTGGGAATG-3' \\
p53 & F: 5'-GTTCTTCACGCCCAAAAGATG-3' & R: 5'-GGACAGTTGGGAAGAGTGTCATT-3' \\
p21 & F: 5'-AGGGGACAGCAGAGGAAG-3' & R: 5'-GCGTTTGGAGTGGTAGAAATCTG-3' \\
GAPDH & F: 5'-ACCTGCCAAATATGATGAC-3' & R: 5'-ACCTGGTGCTCAGTGTAG-3' \\
\hline
\end{tabular}

Immunohistochemical staining. Eighteen anaplastic thyroid cancer slides were deparaffinized in xylene 3 times. Heat antigen retrieval was performed in $10 \mathrm{mM}$ sodium citrate buffer ( $\mathrm{pH}$ 6.0). Non-specific background staining was blocked by incubating in $3 \% \mathrm{H}_{2} \mathrm{O}_{2}$ solution. The primary antibodies Notch1 (1:50), p53 (1:50) (both from Cell Signaling Technology) were used. Finally, all slides were incubated with DAB substrate and counterstained with hematoxylin before they were dehydrated and mounted. The color of the antibody staining in the tissue sections was observed under microscopy.

Statistical analysis. Statistical analyses were performed utilizing the Statistical Package for the Social Sciences (SPSS, version 17; IBM Corp., Armonk, NY, USA). Unless specifically noted, all data are represented as mean \pm SEM. One-way ANOVA or two-tailed Student's t-test was used to determine statistical significance. $\mathrm{P}<0.05$ was considered significant.

\section{Results}

Antitumor roles of SBHA in ATC cell line CAL-62. To study the potential antitumor roles of SBHA, we chose an ATC cell line CAL-62, in which SBHA could significantly inhibit cell viability in a dose-dependent manner detected with MTT assays (Fig. 1). In detail, low concentration of SBHA $(2.5 \mu \mathrm{M})$ could significantly inhibit the proliferation of CAL-62 cells, moreover, $\sim 50 \%$ of cellular growth was inhibited after treatment with $20 \mu \mathrm{M}$ SBHA for $48 \mathrm{~h}$. Notably, we demonstrated that SBHA could induce cell apoptosis detected with apoptosis markers that cleaved caspase-3 and PARP (Fig. 1B). Moreover, the apoptosis cells were identified by flow cytometer as the positive staining with Annexin $\mathrm{V}$ after treatment SBHA for 24-48 h (Fig. 1C). Taken together, all these observations strongly suggested that the SBHA antitumor functions in ACT cells are mainly due to induction of cell apoptosis.

SBHA activates the Notchl signaling cascade. It is known that a functional Notch cascade relies on HDAC activity (17), and previous studies demonstrate that overexpression of Notch1 intracellular domain (NICD) inhibits cell proliferation and restores the differentiated phenotype of thyroid cancer cells $(16,22)$. Therefore, we hypothesized that the HDAC inhibitor SBHA was capable of activating the Notch1 signaling cascade in CAL-62 cells. To this end, we first confirmed the effect of SBHA in CAL-62 cells treated with various concentrations of SBHA. As shown in Fig. 2, SBHA treatment led to a dosedependent increase of Notch1 signaling cascade compared with non-detectable NICD proteins in CAL-62 cells without the treatment of SBHA. These results demonstrated that SBHA activates the Notch1 signaling pathway in CAL-62 cells.

Deletion of Notch1 blocks the SBHA antitumor effects in CAL-62 cells. To determine whether the Notch1 signaling cascade is necessary for SBHA antitumor effects, Notchl was deleted by siRNA in CAL-62 cells, where SBHA-induced expression of NICD could be antagonized by specific siRNA against Notch1, resulted in repressing the Notch1 signaling pathway. These results indicate that SBHA-associated manipulating of Notch1 signaling pathway in CAL-62 cells was mediated by induction of NICD levels (Fig. 3).

Notch1 induces CAL-62 cell apoptosis through p53. To identify the molecular mechanism of SBHA-mediated Notch1dependent cellular apoptosis, we examined the status of the tumor suppressor protein, such as p53 and p21. As shown in Fig. 4, SBHA administration could enhance the expression of p53 and its downstream target p21 in a dose- and time-dependent manner, coupled with increase of Notch1 in CAL-62 cells. Conversely, knockdown of Notch1 could diminish SBHA induced p53 and p21 expression. These results indicate that SBHA induce cell apoptosis partially via regulating the Notch1-mediated p53 and p21 expression.

Notchl is correlated with p53 in human ATC samples. The immunohistochemical staining demonstrated the possible correlation of Notch1 and p53 expression in the anaplastic thyroid cancer samples (Fig. 5), in detail, positive staining of Notch1 and p53 was occurred in the same ATC sample, and all other slides show double negative staining. These results indicate that the possible correlation of Notch1 and p53 pathway, which should mediated SBHA antitumor functions to induce cell apoptosis.

\section{Discussion}

Notch1 is a 300-kDa non-covalent heterodimer consisting of a 180-kDa extracellular domain and a 115-kDa transmembrane domain. Notch1 receptors undergo three distinct proteolytic cleavages during maturation and activation. After that, the intracellular part of the molecule (NICD) binds to RBPJ $\kappa$ (also referred to as CSL and CBF-1), which in its quiescent state, binds to corepressors, including HDACs, thus, regulating the activity of Notch target genes. When NICD binds to RBP-J $\kappa$, it displaces the corepressors; instead, transcriptional co-activators are recruited (23). 


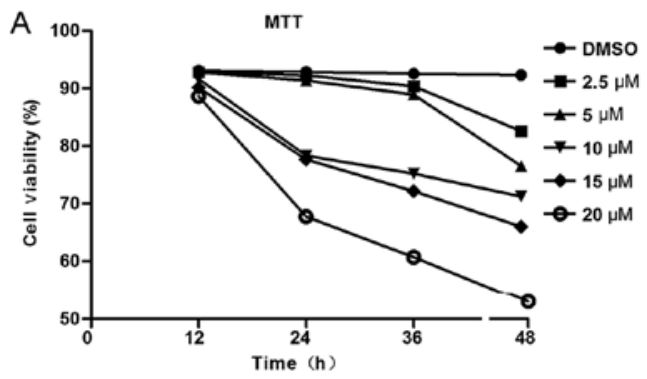

D

Cleaved

parp

Cleaved

caspase 3

Bax

Actin

B

\begin{tabular}{lr} 
& SBHA \\
\hline $2.5 \mu \mathrm{M}$ & $5 \mu \mathrm{M}$
\end{tabular}
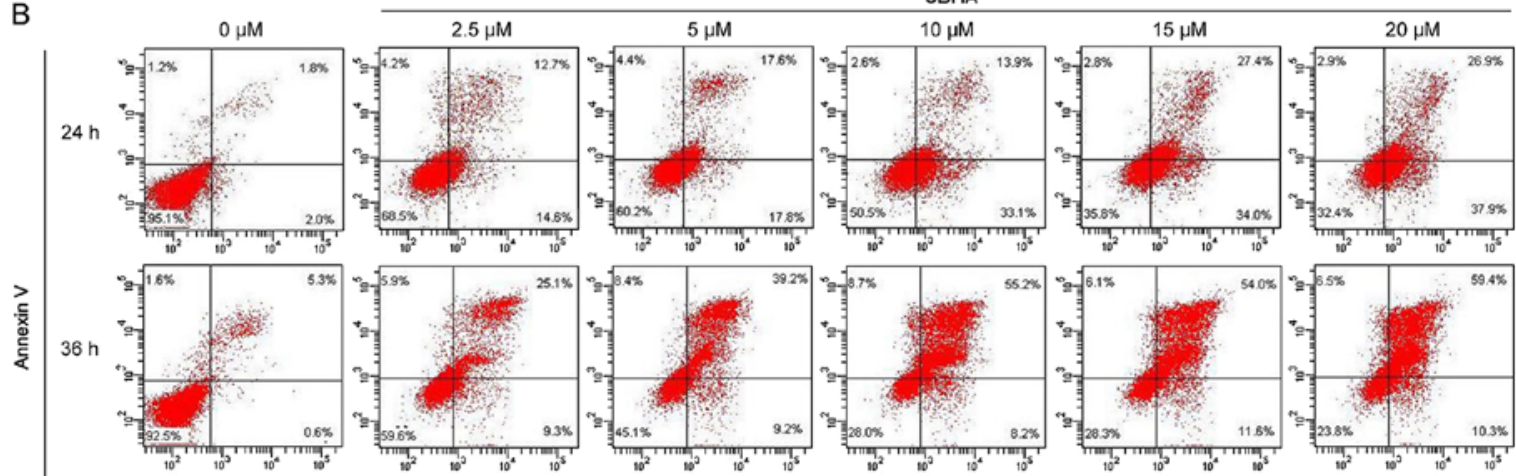

(1)
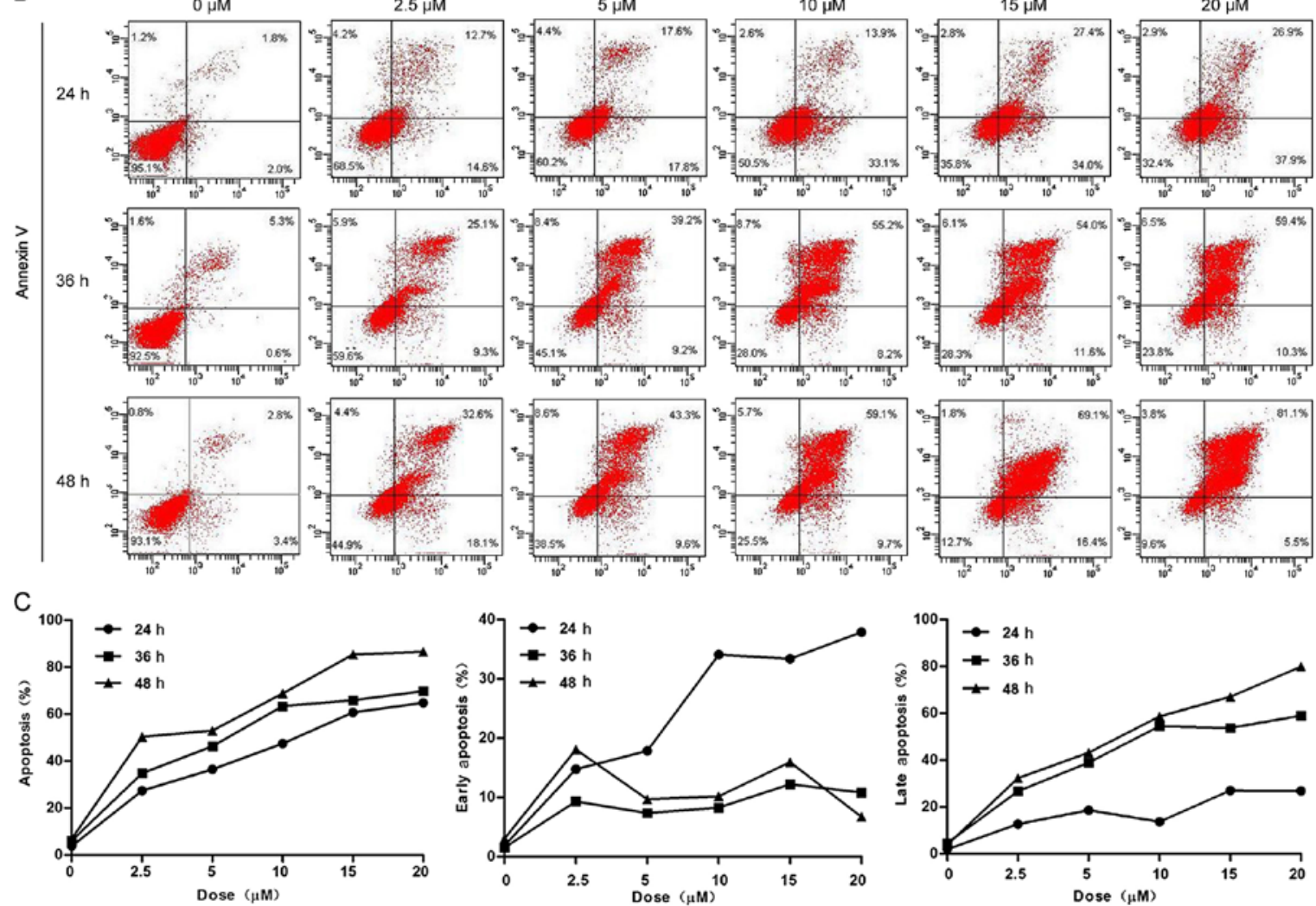

Figure 1. SBHA inhibits anaplastic thyroid cancer cell growth and induces cell apoptosis. (A) CAL-62 cells were treated with different doses (0-20 $\mu \mathrm{M})$ SBHA for $48 \mathrm{~h}$ and cell proliferation was assessed using the MTT assay. P $<0.05$ vs. control. (B) SBHA induced apoptosis in a time- and dose-dependent manner. ATC cell CAL-62 was exposed to different concentrations of SBHA for 24, 36 and $48 \mathrm{~h}$ before they were double stained with Annexin V and PI for flow cytometric analysis. Percentage of early, late and total apoptotic cells exposed to different concentrations of SBHA for 24,36 and $48 \mathrm{~h}$. Data from 3 repeated experiments are summarized in bar graph (C), $\mathrm{P}<0.05$ vs. control cells without SBHA treatment. (D) Detection of apoptotic markers including cleaved-PARP, cleaved-caspase 3 and Bax by western blot analysis in CAL-62 cell treated with 5 different concentrations of SBHA $(2.5,5,10,15$ and $20 \mu \mathrm{M})$ or vehicle control. Equal loading was confirmed with $\beta$-actin.
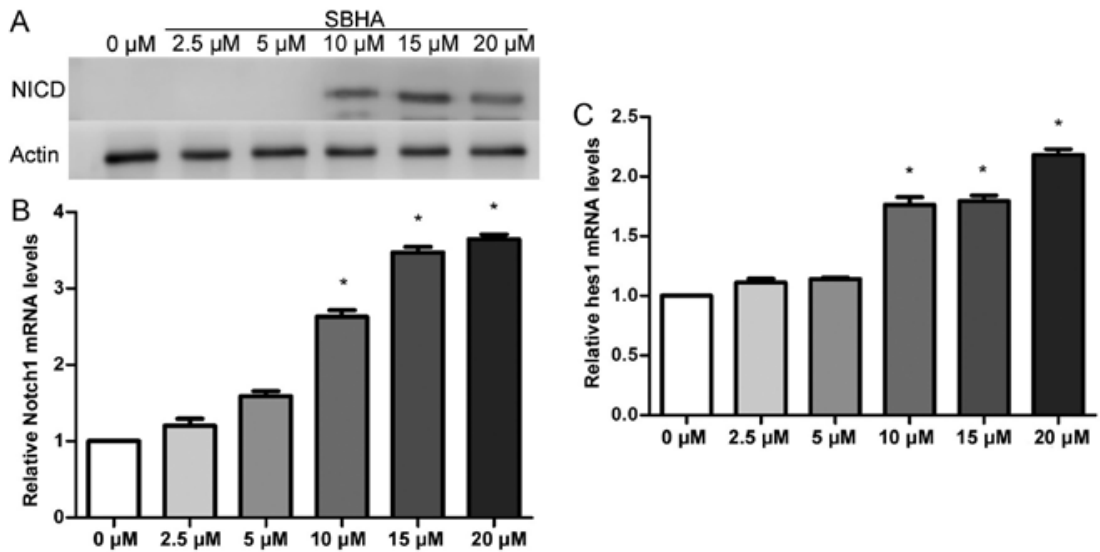

Figure 2. SBHA induces Notch1 expression and contributes activation of Notch1 signal in CAL-62 cells. (A) SBHA treatment resulted in a dose-dependent induction of NICD, the active form of the Notch1 protein. (B and C) With Notch1 activation, there was an increase in Notch1 and HES1, downstream targets of Notch1 signaling in mRNA levels; ${ }^{*} \mathrm{P}<0.05$. 


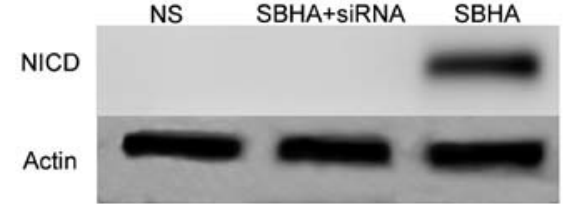

Figure 3. Notch1 RNA interference blocks the effects of SBHA in CAL-62 cells. Cells were transfected with non-targeting or targeting Notch1 siRNA, and then treated with SBHA $(15 \mu \mathrm{M})$ for $48 \mathrm{~h}$.
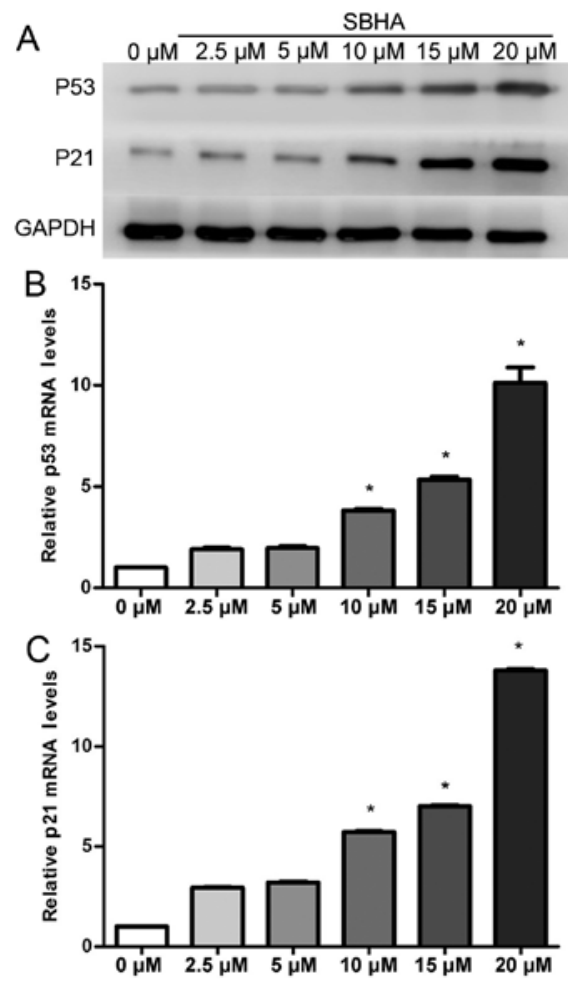

Figure 4. Notch1 induces p53 and p21 expression in a Notch1-dependent manner. After activation of Notch1, p53 and p21 increased the same dosedependent expression both in protein (A) and mRNA (B and C) levels; " $\mathrm{P}<0.05$.

Modification of histones by acetylation and deacetylation affects chromatin structure and plays an important role in the regulation of gene transcription and expression. In addition, it was reported that HDAC inhibitors could upregulate Notch1 signaling in papillary and follicular thyroid cancers, neuroblastoma, and certain neuroendocrine tumors, including small cell lung cancer (24), pheochromocytoma (25), and medullary thyroid carcinoma $(26,27)$. Moreover, Kunnimalaiyaan et al (22) proved that the absence of active Notch1 in these malignant diseases, and that overexpression of Notch1 led to tumor growth suppression, and the degree of growth inhibition is directly proportional to the amount of Notch1 present (28).

Suberoyl bis-hydroxamic acid (SBHA) is a new histone deacetylase (HDAC) inhibitor, and it can activate the Notch1 pathway and lead to a decrease in growth in human medullary thyroid carcinoma (26), neuroblastoma cells (29) and other kinds of cells, which indicated that Notch1 may play a tumorsuppressive role in these carcinomas. Our data demonstrated that SBHA could inhibit proliferation, induce apoptosis in anaplastic thyroid cancer CAL-62 cells. Furthermore, we
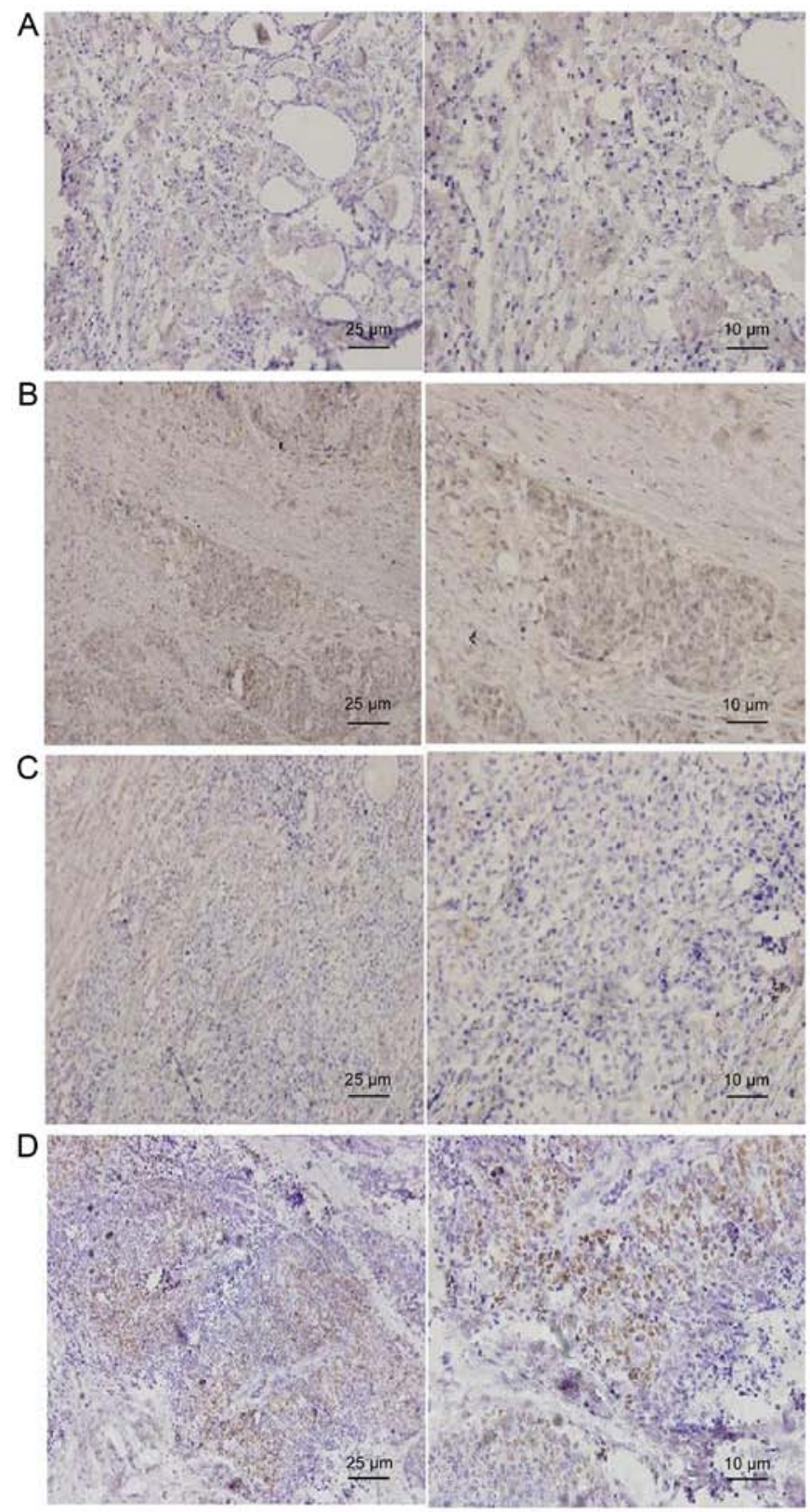

Figure 5. Notch1 expression is correlated with p53 in human ATC samples. (A) Most slides show a negative result of Notch1. (B) Only one slide shows a positive result of Notch1. (C) Most slides show a negative result of p53. (D) Only one slide shows a positive result of p53.

found that SBHA triggered ATC cell apoptosis in a dose- and time-dependent manner, so the number of apoptotic cells increased with time as well as increasing doses of SBHA. Importantly, expression of HES1L-1 did not decrease in ATC cells treated with SBHA when Notch1 signaling was blocked by Notch1-specific siRNA.

Recent results have shown that Notch1 expression regulates cell death through apoptosis (30-32). Therefore, we suspect that the induction of Notch1 by SBHA in ATC cells may be at the transcriptional level. In this study, we observed that levels of active caspase-3 an important effect or of apoptotic cell death, increased in ATC cells treated with SBHA. Proper functioning of active caspase- 3 was subsequently demonstrated by the detection of PARP, one of its cleaved substrates. 
These observations suggest that, after Notch1 signaling activation, SBHA inhibits cell growth through apoptosis in ATC cells. Furthermore, we found that SBHA induced upregulation of the proapoptotic protein BAX. The percentage of apoptotic cells significantly increased after $24 \mathrm{~h}$ of the treatment, suggesting the failure of DNA repair and irreversible transition to apoptosis. This was reflected by the induction of the proapoptotic markers cleaved-PARP and cleaved-caspase- 3 with the concomitant increase in pro-apoptotic markers BAX.

p53 actively promotes apoptosis and plays a key role in controlling tumor growth (33), and its transcriptional function is considered as a marker of large-scale differently expressed genes and involved in cell cycle arrest, which are the main causes of cell apoptosis (34). There are many conflicting conclusions on the reciprocal relationship between Notch signaling and p53 function. First, Notch signaling may upregulate p53 transactivation. It has been demonstrated that $\mathrm{p} 53$-dependent apoptosis increase in cells expressing activated Notch1. The expression of Notch1-IC elevated the levels of nuclear p53 and its target gene transcription in several mammalian cell lines such as hepatocellular carcinoma cells, and human cervical cancer cells (35-37). Second, p53 may negatively regulate Notch signaling. Oswald et al (38) found that p53 competitively binds to the common transcriptional coactivator p300 with Notch1-IC, and it interferes with Notch1-mediated transactivation. Furthermore, p53 downregulates Notch1 activation by enhancing the transcription of $\mathrm{p} 21$ whose expression represses the transcription of the gene for Presenilin-1, which is necessary for Notch activation (39). Third, members of p53 family may activate the Notch signaling pathway. p63 and p73 are p53 family members, they can upregulate transcription of Jag-1 and Jag-2 genes, which encode Notch ligands (40). Fourth, Notch signaling may negatively regulate p53 function and inhibit apoptosis. Overexpression of activated Notch1 decreased p53 transcriptional activity and p53-dependent apoptosis in cultured mammalian cells $(41,42)$.

\section{Acknowledgements}

The present study was partially supported by grants from the National Natural Science Foundation of China (grant nos. 81402392 and 81502322) and the Tianjin Municipal Science and Technology Project (grant no. 15JCQNJC12800).

\section{References}

1. Davies L and Welch HG: Increasing incidence of thyroid cancer in the United States, 1973-2002. JAMA 295: 2164-2167, 2006.

2. Nilubol N and Kebebew E: Should small papillary thyroid cancer be observed? A population-based study. Cancer 121: 1017-1024, 2014.

3. Smallridge RC, Ain KB, Asa SL, Bible KC, Brierley JD, Burman KD, Kebebew E, Lee NY, Nikiforov YE, Rosenthal MS; American Thyroid Association Anaplastic Thyroid Cancer Guidelines Taskforce: American Thyroid Association guidelines for management of patients with anaplastic thyroid cancer. Thyroid 22: 1104-1139, 2012.

4. Kebebew E, Greenspan FS, Clark OH, Woeber KA and McMillan A: Anaplastic thyroid carcinoma. Treatment outcome and prognostic factors. Cancer 103: 1330-1335, 2005.

5. McIver B, Hay ID, Giuffrida DF, Dvorak CE, Grant CS, Thompson GB, van Heerden JA and Goellner JR: Anaplastic thyroid carcinoma: a 50-year experience at a single institution. Surgery 130: 1028-1034, 2001.
6. Sugitani I, Miyauchi A, Sugino K, Okamoto T, Yoshida A and Suzuki S: Prognostic factors and treatment outcomes for anaplastic thyroid carcinoma: ATC Research Consortium of Japan cohort study of 677 patients. World J Surg 36: 1247-1254, 2012.

7. Neff RL, Farrar WB, Kloos RT and Burman KD: Anaplastic thyroid cancer. Endocrinol Metab Clin North Am 37: 525-538, 2008.

8. Chen J, Tward JD, Shrieve DC and Hitchcock YJ: Surgery andradiotherapy improves survival in patients with anaplastic thyroid carcinoma: Analysis of the surveillance, epidemiology, and end results 1983-2002. Am J Clin Oncol 31: 460-464, 2008.

9. O'Neill JP and Shaha AR: Anaplastic thyroid cancer. Oral Oncol 49: 702-706, 2013.

10. Ranganathan P, Weaver KL and Capobianco AJ: Notch signalling in solid tumours: A little bit of everything but not all the time. Nat Rev Cancer 11: 338-351, 2011.

11. Takebe N, Harris PJ, Warren RQ and Ivy SP: Targeting cancer stem cells by inhibiting Wnt, Notch, and Hedgehog pathways. Nat Rev Clin Oncol 18: 97-106, 2011.

12. Kopan R and Ilagan MX: The canonical Notch signaling pathway: unfolding the activation mechanism. Cell 137: 216-233, 2009.

13. Roy M, Pear WS and Aster JC: The multifaceted role of Notch in cancer. Curr Opin Genet Dev 17: 52-59, 2007.

14. Kunnimalaiyaan $\mathrm{M}$ and Chen $\mathrm{H}$ : Tumor suppressor role of Notch-1 signaling in neuroendocrine tumors. Oncologist 12: 535-542, 2007.

15. Xiao X, Ning L and Chen H: Notch1 mediates growth suppression of papillary and follicular thyroid cancer cells by histone deacetylase inhibitors. Mol Cancer Ther 8: 350-356, 2009.

16. Ferretti E, Tosi E, Po A, Scipioni A, Morisi R, Espinola MS, Russo D, Durante C, Schlumberger M, Screpanti I, et al: Notch signaling is involved in expression of thyrocyte differentiation markers and is down-regulated in thyroid tumors. J Clin Endocrinol Metab 93: 4080-4087, 2008.

17. Oswald F, Kostezka U, Astrahantseff K, Bourteele S, Dillinger K, Zechner U, Ludwig L, Wilda M, Hameister H, Knöchel W, et al: SHARP is a novel component of the Notch/RBP-Jkappa signalling pathway. EMBO J 21: 5417-5426, 2002.

18. Federico $M$ and Bagella L: Histone deacetylase inhibitors in the treatment of hematological malignancies and solid tumors. J Biomed Biotechnol 2011: 475641, 2011.

19. Meng J, Zhang HH, Zhou CX, Li C, Zhang F and Mei QB: The histone deacetylase inhibitor trichostatin A induces cell cycle arrest and apoptosis in colorectal cancer cells via p53-dependent and -independent pathways. Oncol Rep 28: 384-388, 2012.

20. Phan T, Yu XM,Kunnimalaiyaan M and Chen H: Antiproliferative effect of chrysin on anaplastic thyroid cancer. J Surg Res 170: 84-88, 2011.

21. Sippel RS, Carpenter JE, Kunnimalaiyaan M, Lagerholm S and Chen H: Raf-1 activation suppresses neuroendocrine marker and hormone levels in human gastrointestinal carcinoid cells. Am J Physiol Gastrointest Liver Physiol 285: G245-G254, 2003.

22. Kunnimalaiyaan M, Vaccaro AM, Ndiaye MA and Chen $\mathrm{H}$ : Overexpression of the NOTCH1 intracellular domain inhibits cell proliferation and alters the neuroendocrine phenotype of medullary thyroid cancer cells. J Biol Chem 281: 39819-39830, 2006.

23. Kao HY, Ordentlich P, Koyano-Nakagawa N, Tang Z, Downes M, Kintner CR, Evans RM and Kadesch T: A histone deacetylase corepressor complex regulates the Notch signal transduction pathway. Genes Dev 12: 2269-2277, 1998.

24. Platta CS, Greenblatt DY, Kunnimalaiyaan M and Chen H: Valproic acid induces Notch1 signaling in small cell lung cancer cells. J Surg Res 148: 31-37, 2008.

25. Adler JT, Hottinger DG, Kunnimalaiyaan M and Chen H: Histone deacetylase inhibitors upregulate Notch-1 and inhibit growth in pheochromocytoma cells. Surgery 144: 956-961, 2008.

26. Ning L, Greenblatt DY, Kunnimalaiyaan M and Chen H: Suberoyl bis-hydroxamic acid activates Notch-1 signaling and induces apoptosis in medullary thyroid carcinoma cells. Oncologist 13: 98-104, 2008

27. Greenblatt DY, Cayo MA, Adler JT, Ning L, Haymart MR, Kunnimalaiyaan M and Chen H: Valproic acid activates Notch1 signaling and induces apoptosis in medullary thyroid cancer cells. Ann Surg 247: 1036-1040, 2008.

28. Ebrahimi M and Shamabadi N: Endocrine disrupting chemicals in pesticides and herbicide in Fars Province, Iran. Pak J Biol Sci 10: 3175-3179, 2007 
29. Stockhausen MT, Sjölund J, Manetopoulos C and Axelson H Effects of the histone deacetylase inhibitor valproic acid on Notch signalling in human neuroblastoma cells. Br J Cancer 92: 751-759, 2005.

30. Kim SB, Chae GW, Lee J, Park J, Tak H, Chung JH, Park TG, Ahn JK and Joe CO: Activated Notch1 interacts with p53 to inhibit its phosphorylation and transactivation. Cell Death Differ 14: 982-991, 2007.

31. Rooman I, De Medts N, Baeyens L, Lardon J, De Breuck S, Heimberg H and Bouwens L: Expression of the Notch signalingpathway and effect on exocrine cell proliferation in adult rat pancreas. Am J Pathol 169: 1206-1214, 2006.

32. Kolev V, Kacer D, Trifonova R, Small D, Duarte M, Soldi R, Graziani I, Sideleva O, Larman B, Maciag T, et al: The intracellular domain of Notch ligand Delta1 induces cell growth arrest. FEBS Lett 579: 5798-5802, 2005.

33. Devine T and Dai MS: Targeting the ubiquitin-mediated proteasome degradation of p53 for cancer therapy. Curr Pharm Des 19 3248-3262, 2013.

34. Shan X, Fu YS, Aziz F, Wang XQ, Yan Q and Liu JW: Ginsenoside $\mathrm{Rg} 3$ inhibits melanoma cell proliferation through down-regulation of histone deacetylase 3 (HDAC3) and increase of p53 acetylation. PLoS One 9: e115401, 2014.

35. Qi R, An H, Yu Y, Zhang M, Liu S, Xu H, Guo Z, Cheng T and Cao X: Notch1 signaling inhibits growth of human hepatocellular carcinoma through induction of cell cycle arrest and apoptosis. Cancer Res 63: 8323-8329, 2003.

36. Talora C, Cialfi S, Segatto O, Morrone S, Kim Choi J, Frati L, Paolo Dotto G, Gulino A and Screpanti I: Constitutively active Notch1 induces growth arrest of HPV-positive cervical cancer cells via separate signaling pathways. Exp Cell Res 305: 343-354, 2005 .
37. Yang X, Klein R, Tian X, Cheng HT, Kopan R and Shen J: Notch activation induces apoptosis in neural progenitor cells through a p53-dependent pathway. Dev Biol 269: 81-94, 2004.

38. Oswald F, Täuber B, Dobner T, Bourteele S, Kostezka U, Adler G, Liptay S and Schmid RM: p300 acts as a transcriptional coactivator for mammalian Notch-1. Mol Cell Biol 21: 7761-7774, 2001.

39. Roperch JP, Alvaro V, Prieur S, Tuynder M, Nemani M, Lethrosne F, Piouffre L, Gendron MC, Israeli D, Dausset J, et al: Inhibition of presenilin 1 expression is promoted by p53 and p21WAF-1 and results in apoptosis and tumor suppression. Nat Med 4: 835-838, 1998

40. Sasaki Y, Ishida S, Morimoto I, Yamashita T, Kojima T, Kihara C, Tanaka T, Imai K, Nakamura Y and Tokino T: The p53 family member genes are involved in the Notch signal pathway. J Biol Chem 277: 719-724, 2002.

41. Nair P, Somasundaram K and Krishna S: Activated Notch1 inhibits p53-induced apoptosis and sustains transformation by human papillomavirus type 16 E6 and E7 oncogenes through a PI3K-PKB/Akt-dependent pathway. J Virol 77: 7106-7112, 2003.

42. Mungamuri SK, Yang X, Thor AD and Somasundaram K: Survival signaling by Notch1: mammalian target of rapamycin (mTOR)-dependent inhibition of p53. Cancer Res 66: 4715-4724, 2006. 